\title{
Green Economy and SMEs in South Africa: How Green are South African SMEs?
}

\section{Evelyn Chiloane-Tsoka}

\author{
College of economic and management sciences, University of South Africa \\ chiloge@unisa.ac.za
}

\section{Junior Mabiza-ma-Mabiza}

Faculty of Engineering and the Built Environment, University of Johannesburg, South Africa
jmabiza@uj.ac.za

\section{Charles Mbohwa}

Faculty of Engineering and the Built Environment, University of Johannesburg, South Africa cmbohwa@uj.ac.za

\section{Doi:10.5901/ajis.2014.v3n6p181}

\section{Abstract}

\begin{abstract}
The setting up of intellectual property support platform in South Africa has been intended to stimulate the development of technology-based services, products, enterprises, and encouraging investment. This initiative is at the heart of the South African National Development Plan (NDP) of 2030. Again, green technology has become a necessity in modern society that in the absence of adequate knowledge will weigh at the expense of any economic objective of any scale to achieve. Green economy has been seen as a great opportunity to boost the global economy and South Africa sees the necessity not to delay to involve its society and already has set targets for 2020 and beyond in the transformation of the natural resource reserves at disposal. A successful South African green economy development would profit the sub-Saharan region and reciprocally, the region would be of an ultimate prospect to benefit the country assuming its position of the regional hub. With this in mind the paper intends to review how possible can an adjustment of SMMEs to green economy occur. SMMEs are the engine of the global economy and the South African economic development aim is a shift to high-value, knowledge-intensive products. The objective of the paper is a conceptual framework and it is based on secondary data collected from government reports, books, internet, archives and current journals, and online publications.
\end{abstract}

Keywords: Green economy, SMEs, technology, intellectual property, youth entrepreneurship, business failure, South Africa.

\section{Introduction}

Green economy is likely to take up all business sectors on the most basic ground of doing business as usual but in an alternative approach that enhances also performance in terms of environmental sound output. Green economy is based on green and renewable technology applications that are as broad and wide as non-green technology applications. Green technology applications have the potential to grow in a larger spectrum; they are expected to perform either to significantly low or non-emitting activity.

The value of South Africa's investment in the green development is growing. The significant competitive advantage for the global green initiatives in view of the country's abundant natural resources deposits is seen as a competitive advantage to foster proactive innovation and create knowledge and human resource capacity for industrial development with a South African advantage of minerals such as platinum group metals of which abundance estimated of about $80 \%$ of the world's reserves, abundant coal reserves, wind and wave energy generation opportunity from a country counting $2,798 \mathrm{~km}$ of coastline sharing with the Indian and the South Atlantic oceans.

Economic development is a priority for South Africa and a shift to high-value, knowledge-intensive products is a national objective. It is intended that investment in Research Development Initiatives will lead to the commercialisation of the resulting technology, leading to increased employment, exports and national wealth (DST, 2007). South Africa for the green development is part of the strategy of paving a path for the economy as a whole to benefit from country's natural resources. For economic benefits to reach the poor and marginalised part of the population, more employment 
opportunities would have to be created (Mange, 2010). South Africa's vision for green technology like platinum based hydrogen fuel cell technology for the onsite energy generation is to develop a number of niche applications in the country and, business wise, conquer the Southern African region. The strategy to a better intervention to the shared benefits by the South African initiatives is to occur in a decentralised nature which SMEs are to play a major role to contribute to the dissemination of services to end-users that are to be supplied even to deep rural areas. The knowledge, awareness, readiness and participative intervention capacity by SMEs on high technology will definitely require high knowledge skills if they have to play their traditional role of contributing to job creation and sustain themselves in the new arena (Mabiza, 2013).

\section{Background}

Most of the work on the green economy worldwide focuses on the policy drivers for stimulating investment in green technologies, creating employment and reducing greenhouse gas emissions. On the other hand, actors who can play a central role in making the green economy a reality are small, micro and medium-sized enterprises (SMMEs) because they are the engine of the global economy (Marquard, 2011).

Consistent with the Eurobarometer - European Commission survey on "SMEs, resource efficiency and green markets", $37 \%$ of European Union SMEs have at least one full or part-time green employee. Green jobs are largely created in SMEs as opposed to large firms. In 2012, 1 in 8 employees of small and medium-sized firms had a green job or almost $13 \%$ of all SME jobs; whereas large firms counted only 1 in 33 equivalents to $3 \%$ of all large company jobs. Green jobs in SMEs were also estimated to expand dynamically with a rate of 35\% in 2014 (SME International, 2012).

The Europe 2020 Strategy recognises the central role of the transition towards a green, low carbon and resource efficient economy in achieving smart, sustainable and inclusive growth. The inefficient use of resources, the unsustainable pressure on the environment, and climate change, as well as social exclusion and inequalities pose challenges to long-term economic growth and an alternative growth model going "beyond GDP" has been on the agenda for many years. A model for green growth - leading to low carbon, climate resilient and resource efficient economy - is used to depict a structural economic change which is mainly driven by scarcity of resources, technological change and innovation, new markets, and changes in industrial and consumer demand patterns (European Commission, 2014).

\section{The South African Perceptive of SMEs}

The South African government has identified the green economy as one of 12 job drivers that could help contribute to what increasingly appears to be a highly ambitious target of creating five-million additional jobs by 2020. In fact, the New Growth Path, in which the sectoral jobs targets are disaggregated, envisages that as many as 300000 new direct jobs could be created in the areas of natural resource management and renewable-energy construction (Vermeulen, 2014).

The historical education system of South Africa has so far led many people without proper education which will not allow them to be participative in the booming of green development. According to Global Entrepreneurship Monitor GEM (2012) many SMEs operators have education level of grade 12 and below. In South Africa, the education and training institutions offer very little entrepreneurial skills training, and as such influence the SME sector negatively (Fatoki, 2010). On the other hand, Ladzani and Van Vuuren (2002) are of the view that although a wide range of education and training programs exist, many institutions conduct training in only one functional area. Creativity is a means to unlock the entrepreneurial potential of individuals, entrepreneurs and organisations, since new ideas and approaches are key ways on promoting an entrepreneurial culture. Furthermore, lack of creativity is a stumbling block to unlock the entrepreneurial potential of individuals, entrepreneurs and organisations, since new ideas and approaches are key ways on promoting an entrepreneurial culture (Fatoki, 2010), while this is a necessity if SMEs are to be encourage and fostered to take opportunities in the countries booming free greenhouse gas development as stimulus for economic growth. The argument lies in response to lack of education that has denied access to majority of the citizens. Green economy by nature will require high level of intelligence and skill for which is a challenge for business entrepreneurs to take advantages of opportunities created by green economy as stimulus of economic growth without having to contribute in their business to the country, heavy carbon footprint emissions.

SMEs are the backbone and catalyst of any developing countries in terms of job creation and poverty alleviation whereas green economy comes as anew sector to provide multiple types of jobs, yet this jobs require high technological skills. In the study conducted by Fatoki (2010) it is observed that while skill and education are the critical baseline for entrepreneurial success it is also noted that SMMEs are expected to be an important vehicle to address the challenges of 
job creation, sustainable economic growth, equitable distribution of income and the overall stimulation of economic development in South Africa (Maas and Herrington, 2006). On the contrary research conducted by Ligthelm (2011) reveals that SMMEs in South Africa suffer from a high failure rate. According to Brink et al. (2003) Ligthelm (2011) articulates that $75 \%$ of new SMMEs created in South Africa fail within the first two years of operation. Also of worthy to note is the fact that SA is lagging behind as compared to other developing countries in as far as promoting the SMMEs sector regardless of government led initiatives.

The sector still faces challenges and of significance is eluded to high level of business failure rate. This is accorded to lack of proper education that could have contributed to high skill and technology base to business planning and managerial knowhow. According to Mange (2010) participating in green economy will require SMMEs owners to have intelligence and skill as green gas stimulus that are highly conceptual in approach. Lack of government intervention in assisting the sector will only worsen the situation. Although the newly appointed minister in her speech accorded that the sector is the only a beacon of hope to job creation (Zulu, 2014). Thus, for SMMEs to take the booming business opportunities provided by green economy much needs to be addressed to educate and train the entrepreneurs.

Similarly there lies some strength in South Africa for young people you are in the majority hit hard by unemployment. The Stats South Africa (2013) indicates that unemployment rate is $27 \%$ and currently $50 \%$ are youth. Mainly from the age group of 24-35. This is a socio-economic problem as it breeds a society that is unstable and crime ridden orchestrated by a need for survival. The demise of the current status quo is further alluded to the fact that the desire to start businesses is almost non-existing by youth (Mthimkulu, 2014). Nonetheless a way forward has been established to encourage youth participation. A funding scheme Youth entrepreneurship fund (YEF) has been launched partnered together with National youth development agency and the youth innovation entrepreneurship to assist with the management of the fund to encourage youth entrepreneurship although, a certain percentage as a start-up capital in a form of collateral will be required. This is intended to provide formal and informal training that will assist them with business models and business plans in order to make them both market and investor ready (ILO, 2014). Of utmost digestion is the fact that young people are the engine of growth if are utilised in a progressive manner. They are energetic and any opportunity of investing in them is an advantage to any country. Globally, there are 1 billion young people between the ages of 15 to 24 as per United Nations (UN) cited by the International labour organisation (ILO, 2012) stating that of those $85 \%$ live in developing countries such as Africa (Botha \& Chiloane-Tsoka, 2013).

It is further anticipated that the coming 10 years the world will experience or see 100 million of young people entering the global workforce (ILO, 2010). Hence, the strategy of South African government to engage in green technology activities as a means of accelerating growth initiative is welcomed with great consideration as a weapon for creating job markets that young people can be targeted as drivers of such government led initiative such as the green technology transformation economy. The youth of today are more into IT, this is demonstrated by the inspiring documentation on Transform Nation by Itumeleng (2014) in Khayelitsha, Western Cape case study.

The South African Youth possess the highly comprehensive knowledge of skill in technology that will respond to the call of green economy. Youth entrepreneurs are noted with courage that once government provide an environment to inculcate and nurture the prioritisation of job creation, youth entrepreneurs should be targeted to pioneer the green economy as means of creating entrepreneurial atmosphere. Training programmes that are in line with transforming technology to green economy should be fostered to create an attractive hope to solve the problem of poverty alleviation. SEDA training programmes should be revolutionised to offer training to more green activity developments.

According to Zikode (2014) in transform nation journal it is pointed out that $45 \%$ of potential and existing businesses access training programmes that are in line with coaching, incubation support. It is hypothetically argued that in essence those who attend are equipped educationally and those who operate in the micro enterprises where the bulk are from disadvantaged do not benefit from this programmes due to lack of access to education and the fact that information dissemination from SEDA structures are not reaching out to the less privileged. Thus, SEDA programmes should foster green technology as niche market to transform the SMMEs sector in a much deeper aggressive manner. It is suggested that the newly elected small business ministry portfolio should identify existing entrepreneurs and small business owners as key stakeholders and engage them from the onset in order to include even youth entrepreneurs to identify what needs to be done (Mabhele, 2014).

\section{Challenges Likely to be Faced by SMEs to Going Green}

Inadequate education in basic sciences, an issue to address to enhance the opportunity of the competence to leading to the feasibility of principles of Sciences highlighting applications; lack of access to skills development and training 
opportunities in entrepreneurship; lack of financial and business skills necessary for sustainable enterprises are major challenges for SMEs to vote in a green development vision as quickly as now. On the other hand, the emanation of these challenges are due to "bound to fail" the efforts of the South African government to address the education system resulting policies not implemented, dead-end development initiatives and skills shortages. Faced with these facts, it might not be possible capacity building to benefit from the funding of major investments to develop green economy fully supporting local SMEs. Expertise could therefore come from abroad with severe consequences on the vision of developing appropriate local industry with local intellectual property and major local financial stakeholders.

Alternatively, training on applications for green technologies by foreign specialists to local SMEs could be essential. Limitations due to lack of triggers from government, financial institutions, and other stakeholders to act quickly to encourage and enable social and environmental activities of SMEs are to be resolved. Within the collimator toward green development, there should be put in place strong mechanisms for reporting and evaluation of pro-poor and nonenvironmental outcomes that would need pro-active critical review and quick action taken to concrete interventions.

The Euro barometer survey also reveals other sources of untapped potential which could be used by SMEs for example, less than a quarter of SMEs take advantage of the single market for green products or services. Bureaucracy is considered as one of the obstacles. $20 \%$ of SMEs says that it would be easier to do green investments if cross-border administrative and legal procedures were not so complex (SME International, 2012).

\section{Financing}

Micro financing opportunities have grown a lot, but start-up enterprises still often face funding difficulties as they have little by way of track record. And even when they have gone some way towards scale up, access to funding and the financial flows from say, the carbon market, is by no means straightforward for (Marquard, 2011).

\section{Appropriate Regulation and Incentives}

The development of standards can provide market rewards; fiscal measures can be targeted at small and micro green businesses; government procurement can stimulate innovation; and help to businesses to find opportunities in addressing challenges such as climate change can reveal innovative solutions appropriate for local problems and so aid adaptation (Marquard, 2011).

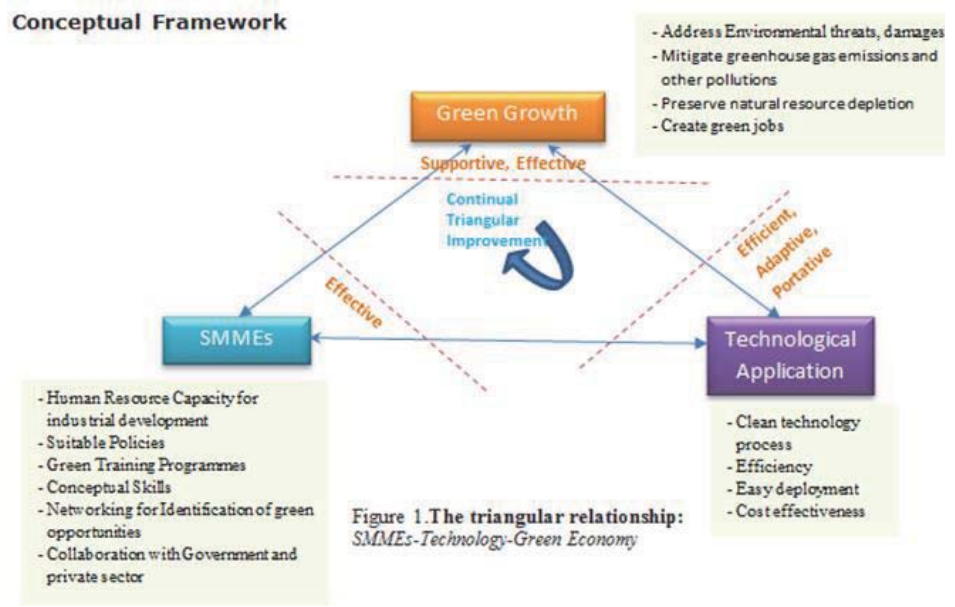

\section{Conclusion}

The creation of knowledge is essential in order to understand new technologies baseline of green economy. This requires the development of high level human resources and the creation of a manufacturing base in the medium and long term. Based on the SA diverse plenty of natural resources the promotion of equity and inclusion in the economic benefits of these resources through green economy implementation will act as enabler of sharing the worth to all the citizens of the country. SMMEs that are within the energy sector in distributing technologies such as solar systems in the household country wide can be seen as just one of the start-ups green technology business which is observed to be successful. 
Mainstreaming the youth into technology that can open into green SMMEs can be one of the best solutions for confronting the setback faced by youth unemployment. Tapping into models or approaches used by experienced communities such as EU, Japan, china and the US will be of valuable contribution. South Africa has the potential to lead the Southern region in green development because it is the stable and strongest node of hub in the region

\section{Recommendations}

- Training programmes of SEDA to be reformed towards green technology

- Training programmes for youth development should be targeted for green economy

- SMMEs should be encouraged to go green beyond non environmental implications of outputs and act as stimulus of growth sustainability.

- SMMEs should venture into energy efficiency housing

- SMMEs should collaborate in joint venturing with heavy manufacturing industry to lobby for skill development and products

- Policy makers should steer the wheel with suitable policies for inclusive programmes on skill sharing

\section{Managerial Implications}

- If well implemented South Africa will be the transformer of its own resources and will locally host its own manufactures;

- SMMEs will benefit from the support of growth of South African booming business;

- Youth unemployment will be reduced;

- Familiarisation of high level technology and fostering Innovation and further high tech jobs;

- Municipalities will benefit from better livelihood value even as far as the rural communities;

- South Africa will reduce its heavy carbon footprint emissions.

\section{References}

Botha, A. and Chiloane-Tsoka, G.E. (2013). Urban Factors influencing urban youth entrepreneurship development in sub-Saharan region. Transform Nation through entrepreneurship magazine, 11, 56-57.

GEM Report (2012). Innovative entrepreneurs focus their growth ambitions on export market

Fatoki, O. (2010). Business failure; An Investigation into the Financial Management Practices of New Micro-enterprises in South. University of Johannesburg, South Africa.

Itumeleng, T. (2014). IT Solutions that create jobs and continue to grow: Transform Nation, 11, 51.

Ladzani WM, Van Vuuren JJ. (2002). Entrepreneurship Training for Emerging SMEs in South Africa. J. Small Bus. Manage, 40:154-161.

Ligthelm, A. (2011). Soweto business Struggling. News24.Com/SA/News/Soweto

ILO. (2010). Urban youth unemployment in the Sub-Saharan region. UN report.

Maas G, Herrington M (2006). Global entrepreneurship monitor: South African report. Graduate School of Business. Cape Town: University of Cape Town.

Mabhele, S. (2014). Creating a sustainable growth for South Africa. Transform Nation, 11, 6.

Mabiza, J. (2013). Unpublished Dissertation: A Project Report in Partial Fulfilment of the Requirement for the Degree of Master of Technology: University of Johannesburg

Mthimkhulu, S. (2014). PR is underestimated by small businesses and government: Transform Nation, 11, 15.

Ndwandwe, E. (2014). New Funda for developing youth entrepreneurs: Transform Nation, 11,15

Marquard, H. (2011). In thinking big, don't forget the real drivers of the economy. http://www.greeneconomycoalition.org/knowhow/thinking-big-dont-forget-real-drivers-economy. Accessed 16/08/2014.

SME International. (2012). SMEs: shift to green economy underway - Eurobarometer survey. http://smeinternational.org/2012/05/smesshift-to-green-economy-underway-eurobarometer-survey/. Accessed 16/08/2014.

Vermeleun, A. (2014). SA's green-jobs focus a good first step, but implementation needs work. http://www.engineeringnews.co.zal article/sas-green-jobs-focus-a-good-first-step-but-implementation-needs-work-2014-06-27

European Commission. (2014). Green Employment Initiative: Tapping into the job creation potential of the green economy. Communication from the commission to the European Parliament, the council, the European economic and social Committee and the committee of the regions.

Zikode, S. (2014). SEDA Enterprise Agency: Transform Nation, Vol, 11, 2014 pp, 8

Zulu, L. (2014). Awards for best achievers: Women's forum Unisa August 2014. University Press. SA 
